\title{
Food habits of snakes from the RPPN Feliciano Miguel Abdala, an Atlantic Forest fragment of southeastern Brazil
}

\author{
Cesar Felipe de Souza Palmuti ${ }^{1}$,José Cassimiro² \& Jaime Bertoluci ${ }^{3,4}$ \\ ${ }^{1}$ Departamento de Zoologia, Instituto de Ciências Biológicas, \\ Universidade Federal de Minas Gerais - UFMG, \\ CP 486, CEP 30123-970, Belo Horizonte, MG, Brazil \\ e-mail: cesarfsp@yahoo.com, http://www.icb.ufmg.br \\ ${ }^{2}$ Departamento de Zoologia, Instituto de Biociências, Universidade de São Paulo - USP, \\ CP 11461, CEP 05422-970, São Paulo, SP, Brazil \\ e-mail: geckoides@usp.br,http://www.icb.usp.br \\ ${ }^{3}$ Departamento de Ciências Biológicas, \\ Escola Superior de Agricultura “Luiz de Queiroz”, Universidade de São Paulo - USP, \\ Av. Pádua Dias, 11, CP 9, CEP 13418-900, Piracicaba, SP, Brazil \\ ${ }^{4}$ Corresponding Author: Jaime Bertoluci,e-mail: bertoluc@esalq.usp.br, http://www.lcb.esalq.usp.br
}

PALMUTI, C.F.S., CASSIMIRO, J. \& BERTOLUCI, J. Food habits of snakes from the RPPN Feliciano Miguel Abdala, an Atlantic Forest fragment of southeastern Brazil. Biota Neotrop., 9(1):http://www.biotaneotropica. org.br/v9n1/en/abstract?short-communication+bn02209012009.

\begin{abstract}
We present data on the diet of 15 species of snakes belonging to a community from Reserva Particular do Patrimônio Natural Feliciano Miguel Abdala, an Atlantic Forest fragment of Southeastern Brazil, based on their stomach contents. For 12 items we were able to determine the direction of the ingestion. Most snakes ingested the prey head-first. A cluster analysis was conducted with items grouped as chilopods, mollusks, adult anurans, anuran tadpoles, lizards, amphisbaenians, snakes, and rodents. The phylogenetic influence on diet preferences is discussed.
\end{abstract}

Keywords: serpentes, diet, feeding ecology, phylogenetic influence on diet, Atlantic Forest.

PALMUTI, C.F.S., CASSIMIRO, J. \& BERTOLUCI, J. Hábito alimentar de serpentes da RPPN Feliciano Miguel Abdala, um fragmento de Mata Atlântica do sudeste do Brasil. Biota Neotrop., 9(1): http://www. biotaneotropica.org.br/v9n1/pt/abstract?short-communication+bn02209012009.

Resumo: Apresentamos aqui a dieta de 15 espécies de serpentes de uma comunidade da Reserva Particular do Patrimônio Natural Feliciano Miguel Abdala, um fragmento de Mata Atlântica do sudeste do Brasil, com base na análise de conteúdos estomacais. Para 12 itens, pudemos determinar o sentido de ingestão da presa. A maioria das serpentes ingeriu a presa no sentido cranial-caudal. Realizamos uma análise de agrupamento reunindo os itens nas categorias quilópodes, moluscos, anuros adultos, girinos, lagartos, anfisbenas, serpentes e roedores. A influência da filogenia sobre a dieta das espécies é discutida.

Palavras-chave: serpentes, dieta, ecologia alimentar, influência da filogenia na dieta, Mata Atlântica. 


\section{Introduction}

Studies on snake feeding ecology are becoming relatively common in recent herpetological literature. The comprehensiveness of these works is somewhat variable, with studies on diet or feeding behavior of particular species or, more frequently, involving snakes of different localities housed in herpetological collections (e.g., Amaral 1924, Lema et al. 1983, Laporta-Ferreira et al. 1986, Sazima \& Martins 1990, Marques \& Puorto 1994, Marques \& Sazima 1997, Pinto \& Lema 2002, Rodríguez-Robles 2002, Nogueira et al. 2003, Hartmann \& Marques 2005). On the other hand, more comprehensive studies involving snake communities or even a limited number of species of the same locality are scarce (e.g., Vitt 1983, Vitt \& Vangilder 1983, Cadle \& Greene 1993, Luiselli et al. 1998, Nogueira et al. 2003, França et al. 2008, Sawaya et al. 2008). Nonetheless, such studies are crucial for the analysis of interspecific relationships and of possible factors organizing natural communities. Phylogeny was considered the major factor determining structure of a snake assemblage from the Cerrado of Central Brazil, with a strong ecological component (França et al. 2008), although co-occurrence analysis of Brazilian Cerrado species and guilds associated to snake diets and habitats suggested a lack of organization (França \& Araújo 2007). Dietary preferences seem to be correlated to local distribution, which represents key information for definition of conservation areas and management plans.

The Atlantic Forest is one of the most fragmented Brazilian ecosystems (Brooks \& Balmford 1996, Fearnside 1996), especially in Minas Gerais State (Machado \& Fonseca 2000). Nevertheless this biome still houses a high diversity of snake species (Marques et al. 2001). We present here data on diet of 16 species of snakes of a small Atlantic Forest fragment of Minas Gerais State based on individuals collected in the field, and compare the pattern of resource use with the phylogeny of involved species.

\section{Material and Methods}

\section{Study site}

This study was conducted at the "Reserva Particular do Patrimônio Natural Feliciano Miguel Abdala" (RPPN-FMA), an Atlantic forest fragment with ca. 957 ha located in the Caratinga municipality, Minas Gerais state, Southeastern Brazil (19 $43^{\circ} \mathrm{S}$ and $\left.41^{\circ} 49^{\prime} \mathrm{W}\right)$, at elevations between 400 and $680 \mathrm{~m}$ (Silva 1993) (Figure 1).

The vegetation that covers the area (the Floresta Tropical Semidecídua Mesofítica Latifoliada; Ab'Saber 1977) presents different stages of regeneration (Hatton et al. 1983) and is dominated by trees belong to the families Leguminosae, Rubiaceae, Asteraceae, Bignoniaceae, and Myrtaceae (Lombardi \& Gonçalves 2000) and by pteridophytes of the families Pteridaceae, Thelypteridaceae, Tectariaceae, Polypodiaceae, Aspleniaceae, and Dennstaedtiaceae (Melo \& Salino 2002).

The climate of the region is characterized by a marked dry season (April to September) and a rainy season (October to March) (Strier 1986). Between August 2000 and July 2001 total annual rainfall was of $865.8 \mathrm{~mm}$ (Figure 2). Annual mean temperature and annual mean precipitation between 1984 and 1985 were of $21.0 \pm 2.8^{\circ} \mathrm{C}$ and 1,133.4 mm, respectively (Hirsch 1995).

The area is considered of "very high biological importance", being designated as priority for the conservation of reptiles and amphibians of the Atlantic Rain Forest (Haddad 2000). Several studies on primates were conducted at the site, involving the species Brachyteles hypoxanthus (Strier 1986, 1991, 1994, 2000), Alouatta guariba (Mendes 1989, Hirsch 1995), Callithrix flaviceps (Ferrari

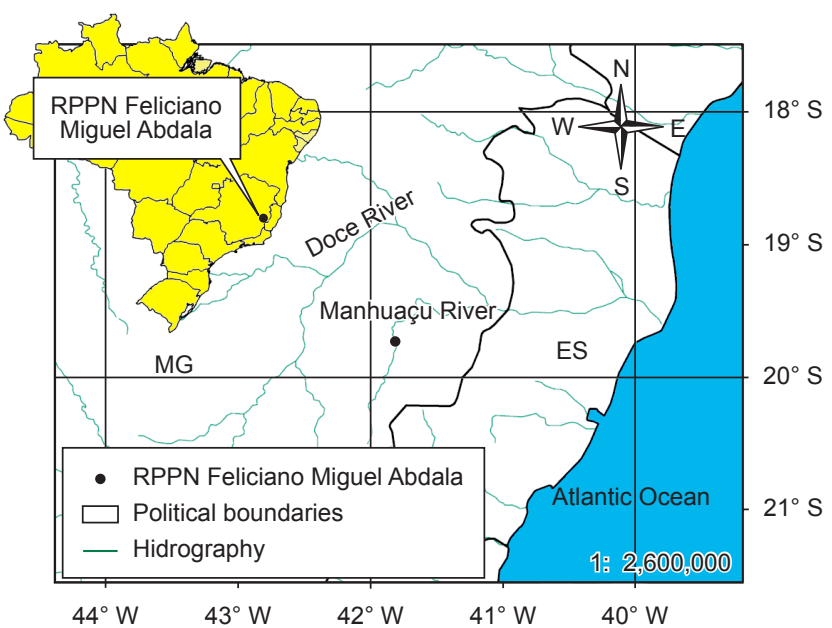

Figure 1. Location of the RPPN Feliciano Miguel Abdala, Caratinga municipality, Minas Gerais state, southeastern Brazil.

Figura 1. Localização da RPPN Feliciano Miguel Abdala, município de Caratinga, estado de Minas Gerais, sudeste do Brasil.

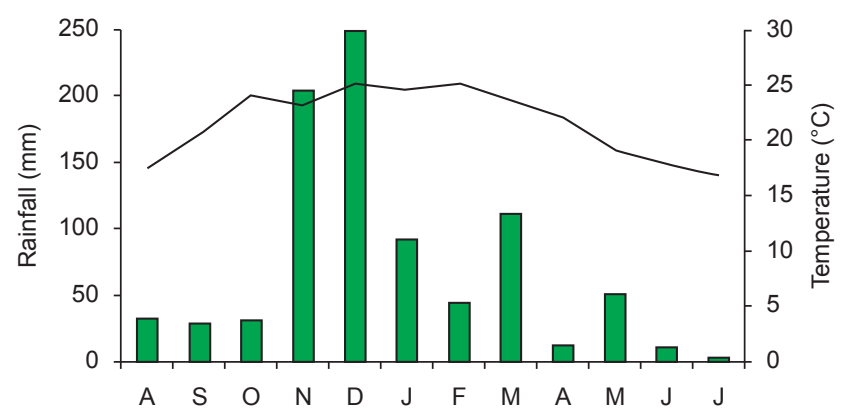

Figure 2. Mean monthly temperature (line) and accumulated monthly precipitation from August 2000 to July 2001 at RPPN-FMA (Karen B. Strier, unpubl. data).

Figura 2. Temperatura mensal média (linha) e precipitação mensal acumulada entre agosto de 2000 e julho de 2001 na RPPN-FMA (Karen B. Stryer, dados não-publicados).

1988, Guimarães 1998), and Cebus nigritus (Lynch \& Rímoli 2000). Other studies on vertebrates included small mammals (Fonseca 1988, 1989, Fonseca \& Kierulff 1988), bats (Aguiar 1994), birds (Machado 1995), and herpetofaunal surveys, which recorded 38 amphibian and 38 reptile species (J. Cassimiro, unpubl. data).

\section{Snake collection and stomach content analysis}

Snakes were collected (by JC) at irregular intervals between July 2000 and July 2001. Specimens were obtained by visual search, casual encounters, collection by other people, and by 40 pitfall traps (volume 20 L) that remained open from December 2000 to April 2001. Immediately after collection, specimens were fixed in $10 \%$ formalin solution and preserved in $70 \%$ alcoholic solution. For the study of the stomach contents, each individual was dissected in the mediumventral region, from the initial portion of the esophagus to the preanal region. The digestive tube was removed, dissected and preserved together with its content in $70 \%$ alcoholic solution. Despite the small 
sample size, a cluster analysis was tentatively carried out based on the presence or absence of prey items grouped in the following categories: chilopods, mollusks, fishes, tadpoles, adult anurans, lizards, amphisbaenians, snakes, and rodents. We used the Euclidean Distance and the method of complete linkage; the analysis was performed with the software Statistica v. $5.0\left(\right.$ StatSoft $\left.^{\circledR}\right)$. When possible, the direction of ingestion of the prey item was determined. Vouchers were deposited in the herpetological collections of Universidade Federal de Minas Gerais (UFMG) and Museu de Zoologia da Universidade de São Paulo (MZUSP); most specimens were not deposited yet, but their field numbers are in Appendix 1, together with museum numbers. All specimens listed by their field numbers in the appendix will be deposited in the MZUSP collection.

\section{Results and Discussion}

We have dissected 90 specimens representing 20 snake species, recording the data on ingestion direction and stomach contents
(Table 1). In this sample, 34 individuals (38\%) of 15 species contained identifiable stomach items. Contents were not found in representatives of two families (15.0\%): the anomalepidid Liotyphlops wilderi $(\mathrm{n}=2)$ and the colubrids Chironius exoletus $(\mathrm{n}=1)$, Elapomorphus quinquelineatus $(\mathrm{n}=2)$, Pseustes sulphureus $(\mathrm{n}=5)$, and Tantilla boipiranga $(\mathrm{n}=2)$. This relatively high proportion of stomachs with food may be related to the fact that snakes were obtained directly from the field, as already pointed out by Nogueira et al. (2003) for Bothrops moojeni in the Brazilian Cerrado, where such proportion was $65.7 \%$.

The 15 snake species feed on nine categories of prey (Table 1). The number of prey categories varied from one (12 snake species) to three (Liophis poecilogyrus, Bothrops jararaca). Rodents, adult anurans and lizards were the most common prey; this pattern is exactly the same detected by França et al. (2008) in the Cerrado of Distrito Federal, Central Brazil. Invertebrates were consumed by B. jararaca (Chilopoda) and Sibynomorphus neuwiedi (Mollusca).

Table 1. Stomach contents and ingestion direction of snakes from the RPPN Feliciano Miguel Abdala, southeastern Brazil. $\mathrm{N}=$ number of snakes; Ns = number of stomaches with contents.

Tabela 1. Conteúdo estomacal e sentido de ingestão da presa em serpentes da RPPN Miguel Feliciano Abdala, sudeste do Brasil. N = número de serpentes; Ns = número de estômagos com conteúdo.

\begin{tabular}{|c|c|c|c|c|}
\hline Snake & $\mathbf{N}$ & Stomach contents & Ns & Ingestion direction \\
\hline \multicolumn{5}{|l|}{ BOIDAE - BOINAE } \\
\hline Corallus hortulanus (Linnaeus, 1758) & 1 & Rodent & 1 & \\
\hline Epicrates cenchria (Linnaeus, 1758) & 1 & Rodent (porcupine spine) & 1 & \\
\hline \multicolumn{5}{|l|}{ COLUBRIDAE - Colubrinae } \\
\hline Chironius fuscus (Linnaeus, 1758) & 6 & Haddadus binotatus & 1 & vent-first \\
\hline Drymoluber dichrous (Peters, 1863) & 2 & Leptodactylid frog & 1 & vent-first \\
\hline Spilotes pullatus (Linnaeus, 1758) & 3 & Rodent & 1 & \\
\hline \multicolumn{5}{|l|}{ COLUBRIDAE - Dipsadinae } \\
\hline Sibynomorphus neuwiedi (Ihering, 1911) & 5 & Veronicellidae (Mollusca) $^{1}$ & 3 & \\
\hline Taeniophallus affinis (Günther, 1858) & 2 & Lizard & 1 & \\
\hline \multicolumn{5}{|l|}{ COLUBRIDAE - Xenodontinae } \\
\hline \multirow[t]{2}{*}{ Erythrolamprus aesculapii (Linnaeus, 1766) } & 4 & Elapomorphus quinquelineatus & 1 & head-first \\
\hline & & Colubrid snake & 1 & tail-first \\
\hline Liophis miliaris (Linnaeus, 1758) & 2 & Tadpoles $^{2}$ & 1 & \\
\hline \multirow[t]{6}{*}{ Liophis poecilogyrus (Wied-Neuwied, 1825) } & 12 & Physalaemus sp.1 & 2 & head-first \\
\hline & & Physalaemus sp.2 & 1 & head-first \\
\hline & & Leptodactylid frog & 1 & head-first \\
\hline & & Undetermined anuran & 1 & \\
\hline & & Newly hatched tadpoles ${ }^{3}$ & $?^{4}$ & \\
\hline & & Fish & 1 & \\
\hline Oxyrhopus petola (Linnaeus, 1758) & 2 & Lizard & 1 & \\
\hline \multirow[t]{2}{*}{ Pseudoboa nigra (Duméril, Bibron \& Duméril, 1854) } & 6 & Lizard & 1 & \\
\hline & & Rodent & 1 & \\
\hline \multicolumn{5}{|l|}{ ELAPIDAE } \\
\hline Micrurus corallinus (Merrem, 1820) & 5 & Amphisbaenidae & 1 & \\
\hline \multicolumn{5}{|l|}{ VIPERIDAE } \\
\hline \multirow{6}{*}{ Bothrops jararaca (Wied-Neuwied, 1824) } & 25 & Scolopendra sp. (Chilopoda) & 1 & \\
\hline & & Haddadus binotatus & 1 & head-first \\
\hline & & Leptodactylus sp. (gr. notoaktites) & 2 & head-first \\
\hline & & Leptodactylus sp. & 1 & \\
\hline & & Hylid frog & 1 & head-first \\
\hline & & Rodent & 8 & \\
\hline Bothrops jararacussu Lacerda, 1884 & 2 & Rodent & 1 & \\
\hline
\end{tabular}

${ }^{1}$ Sarasinula sp. $(\mathrm{n}=4)$, undeterm. $(\mathrm{n}=2) ;{ }^{2}$ Leptodactylidae $(\mathrm{n}=6)$, Hylidae $(\mathrm{n}=2)$, undeterm. $(\mathrm{n}=3) ;{ }^{3}$ undeterm. $(\mathrm{n}=214) ;{ }^{4}$ missing data. 
In fact several species of Bothrops feed on chilopods (Martins et al. 2002, Valdujo et al. 2002, Nogueira et al. 2003), and Sibynomorphus spp. are specialized on mollusks (Laporta-Ferreira et al. 1986, Oliveira 2001, França et al. 2008). The fact that most species ingested a single type of prey should be viewed as a result of our small sample size, but some of these species are really food specialists, including S. neuwiedi (mollusks; Laporta-Ferreira et al. 1986, Marques et al. 2001), Chironius fuscus (anurans; Strüssmann \& Sazima 1993, Marques et al. 2001, Sawaya et al. 2008), Pseudoboa nigra (lizards; Vitt \& Vangilder 1983), Erythrolamprus aesculapii (snakes; Greene 1976, Marques \& Puorto 1994, Marques et al. 2001), and Micrurus corallinus (amphisbaenians and snakes; Marques et al. 2001). Ingestion of fishes by L. poecilogyrus was rarely reported in the literature (e.g. Giraudo et al. 2007), and several works failed to detect ichthyophagy in this species (e.g., Marques et al. 2001, Pinto \& Fernandes 2004, França et al. 2008, Sawaya et al. 2008); this food habit is common in L. miliaris (e.g., Marques et al. 2001). The presence of spines of a porcupine (Erethizontidae, Rodentia) in the stomach of the boid Epicrates cenchria represents a novelty for the diet of this genus (Cassimiro et al., in press), although it has already been observed for other boid genera and even in other families (Duarte 2003).

The direction of ingestion was determined for 12 prey items, two of which were snakes and nine were anuran amphibians. One snake and two anurans had been ingested tail-first (vent-first in the case of anurans), while one snake and seven anurans had been ingested head-first. Most snakes swallow prey head-first (e.g., Klein \& Loop 1975, Greene 1976, Mori 1996), and this behavior seems to be related to a decrease in both swallowing time and probability of injury during prey handling (Greene 1976). The tail-first ingestion of snakes, L. poecilogyrus, by individuals of the colubrid E. aesculapii registered two times during the field work (JC) corroborates the observations of Greene (1976) and Marques \& Puorto (1994). In this species, tailfirst ingestion seems to be a specialization to ophiophagy, associated to the opistoglyph dentition and hypertrophied Duvernoy's glands (Marques \& Puorto 1994).
In some cases, the result of the cluster analysis (Figure 3) suggests an influence of phylogeny on diet - e.g. in the boids Corallus hortulanus and Epicrates cenchria (mammals) and in the colubrines C. fuscus and Drymoluber dichrous (anurans). The two boids also prey on birds (Henderson 1993, Marques et al. 2001). Although many colubrines typically feed on anurans, the ingestion of lizards and snakes by $D$. dichrous was previously reported (Cunha \& Nascimento 1978, Cunha et al. 1985, Dixon \& Soini 1986, Martins 1994, Borges-Nojosa \& Lima 2001, Pinto 2006). For the Xenodontinae, the separation of the species studied in different groups may reflect the capture behavior and subjugation of prey, an effect of body size (Cadle \& Greene 1993). A larger sample size would probably bring separate groups together.

Our data are not conclusive regarding the analysis of the interspecific relationships within the community. França \& Araújo (2007) suggested that the importance of certain ecological factors (in this case, diet, which reflects predator-prey relationship and intra- and interspecific competition) becomes clearer in communities with sympatric species of great abundance. In a more robust study, França et al. (2008) concluded that phylogeny is the most important factor determining the structure of a snake community of Central Brazil Cerrado, with ecological factors also playing an important role. The influence of both historical and ecological factors on squamate assemblages was already suggested for snakes (Guyer \& Donnelly 1990), Bothrops spp. (Martins et al. 2001, 2002), and lizards (Mesquita et al. 2007).

Thus, studies involving larger numbers of individuals and considering ontogenetic variation in diet could provide insights into the relative influence of ecological and historical factors on snake community structure.

\section{Acknowledgements}

We are grateful to Teofânia Vidigal, Mauro Luiz Triques, Éwerton Machado, Lângia Montressor and Bárbara N. Costa for help in the

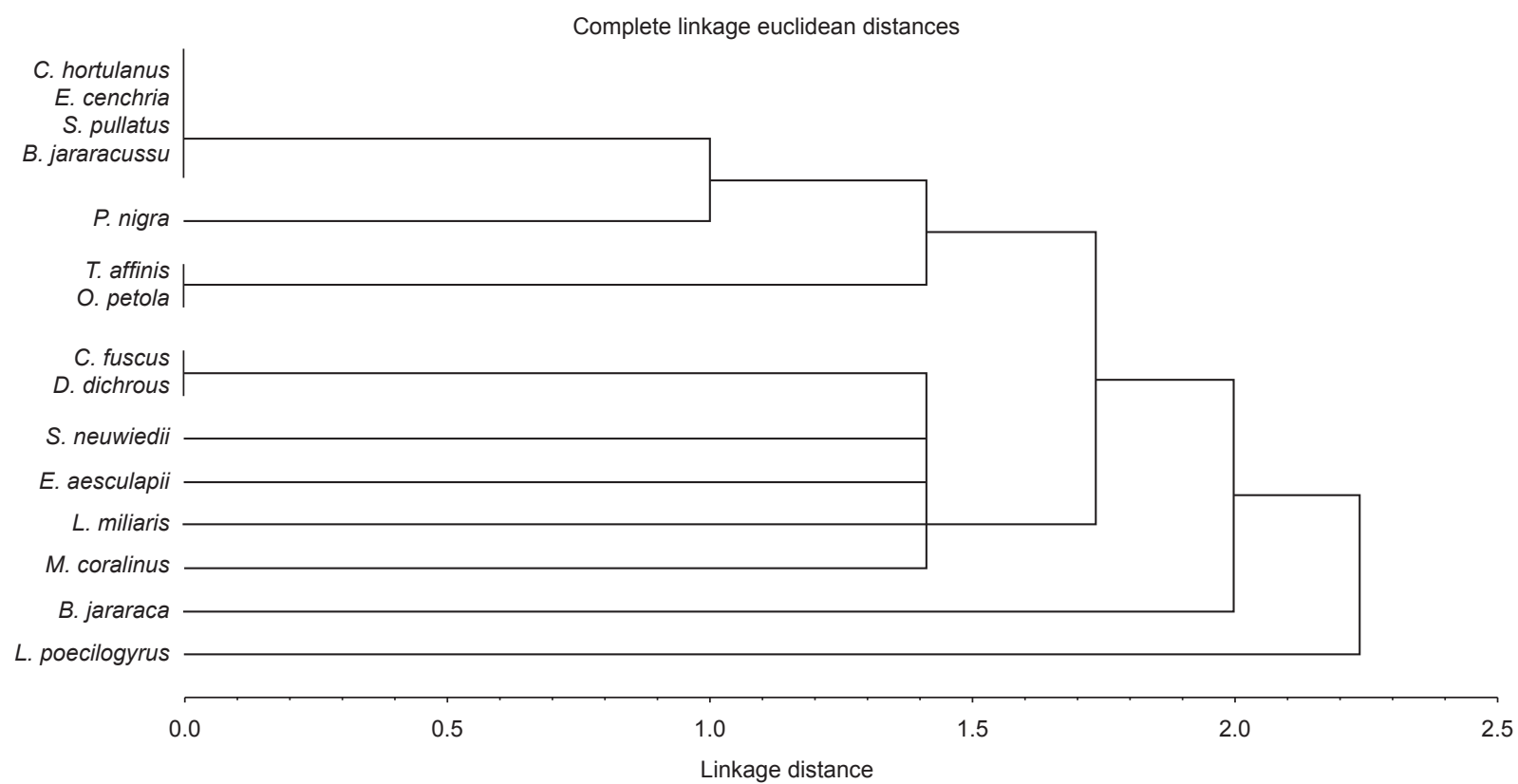

Figure 3. Cluster analysis (complete linkage, Euclidean distances) of diet items grouped as chilopods, mollusks, fishes, tadpoles, adult anurans, lizards, amphisbaenians, snakes, and rodents.

Figura 3. Análise de agrupamento (ligação completa, distâncias Euclidianas) dos itens da dieta agrupados como quilópodes, moluscos, peixes, girinos, anurosadultos, lagartos, anfisbenas, serpentes e roedores. 
identification of prey items; Jairo V. Gomes, Vanessa Guimarães, Waldney Pereira Martins, Eduardo Marcelino Veado (in memory), D. Judeci (Lada), and D. Vera also helped to collect snakes. Felipe F. Curcio, Cristiano Nogueira and two anonymous referees critically reviewed the manuscript. Snake identification was verified by Felipe F. Curcio. JC also thank Karen B. Strier for the facilities during the accomplishment of the field work and for the grants during his permanence in the RPPN-FMA through the following institutions: Margot Marsh Biodiversity Foundation, Liz Claiborne and Art Ortenberg Foundation, National Geographic Society and Graduate School of the Wisconsin-Madison University. Karen B. Strier kindly provided climate data. JB is researcher of the CNPq.

\section{References}

AB'SABER, A.N. 1977. Os domínios morfo-climáticos na América do Sul: primeira aproximação. Geomorfologia, 52(1):1-22.

AGUIAR, L.M.S. 1994. Comunidades de Chiroptera em três áreas de Mata Atlântica em diferentes estágios de sucessão - Estação Biológica de Caratinga, Minas Gerais. Dissertação de Mestrado, Universidade Federal de Minas Gerais, Belo Horizonte.

AMARAL, A. 1924. Contribuição à biologia dos ophidios brasileiros (habitat, hábitos e alimentação). Collect. Trab. Inst. Butantan, 2:177-181.

BORGES-NOJOSA, D.M. \& LIMA, D.C. 2001. Dieta de Drymoluber dichrous (Peters, 1863) dos brejos-de-altitude do estado do Ceará, Brasil (Serpentes, Colubridae). Bol. Mus. Nac. 468:1-5.

BROOKS, T. \& BALMFORD, A. 1996. Atlantic Forest extinctions. Nature, $380: 115$.

CADLE, J.E. \& GREENE, H.W. 1993. Phylogenetic patterns, biogeography, and the ecological structure of Neotropical snake assemblages. In Species diversity in ecological communities (R.E. Ricklefs \& D. Schluter, eds.). Chicago University Press, Chicago, p. 281-293.

CASSIMIRO, J., PALMUTI, C.F.S. \& BERTOLUCI, J. Epicrates cenchria (Salamanta; Rainbow Boa). Diet. Herpetol. Rev. In press.

CUNHA, O.R. \& NASCIMENTO, F.P. 1978. Ofídios da Amazônia. X: as cobras da região leste do Pará. Publ. Avul. Mus. Par. Emílio Goeldi 31:1-218.

CUNHA, O.R., NASCIMENTO, F.P. \& AVILA-PIRES, T.C.S. 1985. Os répteis da área de Carajás, Pará, Brasil (Testudines e Squamata). I. Publ. Avul. Mus. Par. Emílio Goeldi, 40:10-92.

DIXON, J.R. \& SOINI, P. 1986. The reptiles of the upper Amazon Basin, Iquitos Region, Peru. Milwaukee, Wisconsin. Milwaukee Publ. Mus.

DUARTE, M.R. 2003. Prickly food: snakes preying upon porcupines. Phyllomedusa, 2(2):109-112.

FEARNSIDE, P.M. 1996. Brazil. In The conservation atlas of tropical forests: the Americas (C.S. Harcourt \& J.A. Sayer, eds.). Simon and Schuster, New York, p. 229-248.

FERRARI, S.F. 1988. The bahaviour and ecology of the buffy-headed marmoset, Callithrix flaviceps (O. Thomas, 1903). Tese de Doutorado, University College, England.

FONSECA, G.A.B. 1988. Patterns of small mammal diversity in the Brazilian Atlantic Forest. Tese de Doutorado, University of Florida, Gainesville.

FONSECA, G.A.B. 1989. Small mammals species diversity in Brazilian tropical primary and secondary forests of different sizes. Rev. Brasil. Zool. 6(3):381-422.

FONSECA, G.A.B. \& KIERULFF, M.C.M. 1988. Biology and natural history of Brazilian Atlantic Forest small mammals. Bull. Florida State Mus. Biol. Sci. 34(1):99-152.

FRANÇA, F.G.R. \& ARAÚJO, A.F.B. 2007. Are there co-occurrence patterns that structure snake communities in Central Brazil? Braz. J. Biol. 67(1):33-40.

FRANÇA, F.G.R., MESQUITA, D.O., NOGUEIRA, C.C. \& ARAÚJO, A.F.B. 2008. Phylogeny and ecology determine morphological structure in a snake assemblage in the Central Brazilian Cerrado. Copeia, 2008(1):20-36.
GIRAUDO, A.R., ARZAMENDIA, V. \& LÓPEZ, S.M. 2007. Reptiles. In The Middle Paraná River: limnology of a subtropical wetland (M.H. Iriondo, J.C. Paggi \& M.J. Parma, eds.). Springer, Berlin, p. 341-362.

GREENE, H.W. 1976. Scale overlap, a directional sign stimulus for prey ingestion by ophiophagous snakes. Z. Tierpsychol. 41(1):113-120.

GUIMARÃES, A. 1998. Ecologia, comportamento reprodutivo e marcação de cheiro em um grupo de Callithrix flaviceps (Callitrichidae, Primates), na Estação Biológica de Caratinga, Minas Gerais. Dissertação de Mestrado, Universidade Federal de Minas Gerais, Belo Horizonte.

GUYER, C. \& DONNELLY, M.A. 1990. Length-mass relationships among an assemblage of tropical snakes in Costa Rica. J. Tropical Ecol. 6(1):65-76.

HADDAD, C.F.B. 2000. Anfíbios e Répteis. In Avaliação e ações prioritárias para a conservação da biodiversidade da Mata Atlântica e Campos Sulinos (Conservation International do Brasil, Fundação SOS Mata Atlântica, Fundação Biodiversitas, Instituto de Pesquisas Ecológicas, Secretaria do Meio Ambiente do Estado de São Paulo and SEMAD/ Instituto Estadual de Florestas, eds.). Ministério do Meio Ambiente, Brasília, p. 19-21.

HATTON, J., SMART, N. \& THONSON, K. 1983. In urgent need of protection-habitat for the woolly spider monkey. Oryx, 18(1):24-29.

HARTMANN, P.A. \& MARQUES, O.A.V. 2005. Diet and habitat use of two sympatric species of Philodryas (Colubridae) in south Brazil. AmphibiaReptilia, 26(1):25-31.

HENDERSON, R.W. 1993. On the diets of some arboreal boids. Herpetol. Nat. Hist. 1(1):91-96.

HIRSCH, A. 1995. Censo de Alouatta fusca Geoffroy, 1812 (Platyrrhyni, Atelidae) e qualidade do habitat em dois remanescentes de Mata Atlântica em Minas Gerais. Dissertação de Mestrado, Universidade Federal de Minas Gerais, Belo Horizonte.

KLEIN, J. \& LOOP, M.S. 1975. Headfirst prey ingestion by newborn Elaphe and Lampropeltis. Copeia, 1975(2):366.

LAPORTA-FERREIRA, I.L., SALOMÃO, M.G. \& SAWAYA, P. 1986. Biologia de Sibynomorphus (Colubridae - Dipsadinae): reprodução e hábitos alimentares. Rev. Brasil. Biol. 46(4):793-799.

LEMA, T., ARAÚJO, M.L. \& AZEVEDO, A.C.P. 1983. Contribuição ao conhecimento da alimentação e do modo alimentar de serpentes do Brasil. Comun. Mus. Ciênc. PUCRS, Sér. Zool. 26(1):41-121.

LOMBARDI, J.A. \& GONÇALVES, M. 2000. Composição florística de dois remanescentes de Mata Atlântica do sudeste de Minas Gerais, Brasil. Rev. Brasil. Bot. 23:255-282.

LUISELLI, L., AKANI, G.C. \& CAPIZZI, D. 1998. Food resource partitioning of a community of snakes in a swamp rainforest of south-eastern Nigeria. J. Zool. 246(2):125-133.

LYNCH, J.W. \& RÍMOLI, J. 2000. Demography of a group of tufted capuchin monkeys (Cebus apella nigritus) at the Estação Biológica de Caratinga, Minas Gerais, Brazil. Neotrop. Primates, 8(1):44-49.

MACHADO, R.B. 1995. Padrão de fragmentação da Mata Atlântica em três municípios da Bacia do Rio Doce (Minas Gerais) e suas conseqüências para a avifauna. Dissertação de Mestrado, Universidade Federal de Minas Gerais, Belo Horizonte.

MACHADO, R.B. \& FONSECA, G.A.B. 2000. The avifauna of Rio Doce Valley, southeastern Brazil, a highly fragmented area. Biotropica, 32(4):914-924.

MARQUES, O.A.V. \& PUORTO, G. 1994. Dieta e comportamento alimentar de Erythrolamprus aesculapii, uma serpente ofiófaga. Rev. Brasil. Biol. 54(2):253-259.

MARQUES, O.A.V. \& SAZIMA, I. 1997. Diet and feeding behavior of the coral snake, Micrurus corallinus, from the Atlantic Forest of Brazil. Herpetol. Nat. Hist. 5(1):88-93.

MARQUES, O.A.V., ETEROVIC, A. \& SAZIMA, I. 2001. Serpentes da Mata Atlântica: guia ilustrado para a Serra do Mar. Holos Editora, Ribeirão Preto.

MARTINS, M. 1994. História natural e ecologia de uma taxocenose de serpentes em mata ripária na região de Manaus, Amazônia Central, Brasil. Tese de Doutorado, Universidade Estadual de Campinas, Campinas. 
MARTINS, M., ARAUJO, M.S., SAWAYA, R.J. \& NUNES, R. 2001. Diversity and evolution of macrohabitat use, body size and morphology in a monophyletic group of Neotropical pitvipers (Bothrops). J. Zool. 254(4):529-538.

MARTINS, M., MARQUES, O.A.V. \& SAZIMA, I. 2002. Ecological and phylogenetic correlates of feeding habits in Neotropical pitvipers of the genus Bothrops. In Biology of the Vipers (G.W. Schuett, M. Höggren, M.E. Douglas \& H.W. Greene, eds.). Eagle Mountain Publishing, Eagle Mountain, p. 307-328.

MELO, L.C.N. \& SALINO, A. 2002. Pteridófitas de duas áreas de floresta da Bacia do Rio Doce no Estado de Minas Gerais, Brasil. Lundiana, 3(2):129-139.

MENDES, S.L. 1989. Estudo ecológico de Alouatta fusca (Primates: Cebidae) na Estação Biológica de Caratinga, MG. Rev. Nordestina Biol. 6(2):71-104.

MESQUITA, D.O., COLLI, G.R. \& VITT, L.J. 2007. Ecological release in lizard assemblages of Neotropical savannas. Oecologia, 153(1):185-195.

MORI, A. 1996. A comparative study of the development of prey handling behavior in young rat snakes, Elaphe quadrivirgata and E. climacophora. Herpetologica, 52(3):313-322.

NOGUEIRA, C., SAWAYA, R.J. \& MARTINS, M. 2003. Ecology of the pitviper, Bothrops moojeni, in the Brazilian Cerrado. J. Herpetol. 37(4):653-659.

OLIVEIRA, J.L. 2001. Ecologia de três espécies de dormideira Sibynomorphus (Serpentes, Colubridae). Dissertação de Mestrado, Universidade de São Paulo, São Paulo.

PINTO, R.R. 2006. Drymoluber dichrous (NCN). Ophiophagy. Herpetol. Rev. 37(2):231.

PINTO, R.R. \& FERNANDES, R. 2004. Reproductive biology and diet of Liophis poecilogyrus poecilogyrus (Serpentes, Colubridae) from southeastern Brazil. Phyllomedusa, 3(1):9-14.

PINTO, C.C. \& LEMA, T. 2002. Comportamento alimentar e dieta de serpentes, gêneros Boiruna and Clelia (Serpentes, Colubridae). Iheringia, Sér. Zool. 92(1):9-19.
RODRÍGUEZ-ROBLES, J.A. 2002. Feeding ecology of North American gopher snakes (Pituophis catenifer, Colubridae). Biol. J. Linn. Soc. 77(2):165-183.

SAWAYA, R.J., MARQUES, O.A.V. \& MARTINS, M.R.C. 2008. Composição e história natural das serpentes de Cerrado de Itirapina, São Paulo, sudeste do Brasil. Biota Neotrop. 8(2): http://www.biotaneotropica.org.br/v8n2/ pt/abstract?article+bn01308022008 ISSN 1676-0603. (último acesso em 13/02/2009).

SAZIMA, I. \& MARTINS, M. 1990. Presas grandes e serpentes jovens: quando os olhos são maiores que a boca. Mem. Inst. Butantan, 52(3):73-79.

SILVA, L.V.C. 1993. Comparação fitossociológica entre duas amostragens numa área de clareira em anos consecutivos, Estação Biológica de Caratinga, MG. Acta Bot. Bras. 7(1):119-127.

STRIER, K.B. 1986. The behavior and ecology of the wooly spider monkey, or muriqui (Brachyteles arachnoides E. Geoffroy, 1806). Tese de Doutorado, University of Harvard, Cambridge.

STRIER, K.B. 1991. Demography and conservation of and endangered primate, Brachyteles arachnoides. Conserv. Biol. 5(2):214-218.

STRIER, K.B. 1994. Viability analysis of an isolated population of Muriqui monkeys (Brachyteles arachnoides): implications for primate conservation and demography. Primate Conserv. 14-15:43-52.

STRIER, K.B. 2000. Population viabilities and conservation implications for muriquis (Brachyteles arachnoides) in Brazil's Atlantic Forest. Biotropica, 32(4b):903-913.

STRÜSSMANN, C. \& SAZIMA, I. 1993. The snake assemblage of the Pantanal at Poconé, western Brazil: faunal composition and ecological summary. Stud. Neotrop. Fauna Environ. 28(3):157-168.

VALDUJO, P.H., NOGUEIRA, C.C. \& MARTINS, M. 2002. Ecology of Bothrops neuwiedi pauloensis (Serpentes: Viperidae: Crotalinae) in the Brazilian Cerrado. J. Herpetol. 36(2):169176.

VITT, L.J. 1983. Ecology of an anuran-eating guild of terrestrial tropical snakes. Herpetologica, 39(1):52-66.

VITT, L.J. \& VANGILDER, L.D. 1983. Ecology of a snake community in northeastern Brazil. Amphibia-Reptilia, 4(2-4):273-296.

Recebido em 13/09/08 Versão Reformulada recebida em 19/02/09 Publicado em 25/02/09 
Appendix 1. Material Examined

Apêndice 1. Material Examinado

Bothrops jararaca: JC 3, 28, 49, 113, 116-8, 125, 147, 176, 233, 275, 278, 281-2, 298, 321, 523-6, 730, 736-7. Bothrops jararacussu: JC 50, 518. Chironius exoletus: JC 126. Chironius fuscus: JC 29, 30, 33, 115, 279, 452. Corallus hortulanus: JC 25. Drymoluber dichrous: UFMG 1397 (= JC 122), UFMG 1398 (= JC 541). Elapomorphus quinquelineatus: JC 27, 114. Epicrates cenchria: MZUSP 14474 (= JC 517). Erythrolamprus aesculapii: JC 26, 127, 522, 738. Liophis miliaris: JC 260, 357. Liophis poecilogyrus: JC 32, 234-5, 274, 280, 322, 473, 537-9, 710, 739. Liotyphlops wilderi: JC 119-20. Micrurus corallinus: JC 136, 228-9, 318, 527. Oxyrhopus petola: JC 62, 231. Pseudoboa nigra: JC 121, 138, 390, 520-1, 459. Pseustes sulphureus: JC 146, 284, 316, 408, 454. Sibynomorphus neuwiedi: JC 34, 63, $236,530,735$. Spilotes pullatus: JC 112, 460, 519. Taeniophallus affinis: JC 61, 457. Tantilla boipiranga: UFMG 1402 (= JC 299 ), JC 531.

$\mathrm{JC}=$ field number of José Cassimiro; MZUSP = Museu de Zoologia da Universidade de São Paulo. UFMG = herpetological collection of Universidade Federal de Minas Gerais 
